\title{
On Dharmakirti's Proof of the Existence of External Objects*
}

\section{Taiken KYŪMA}

1. It is a well-known fact that Dharmakirti makes reference to the proof of the existence of external objects (bāhy'ärtha) in PV III 390d-39lab and PVin I 59d. According to this theory, which has been ascribed to the Sauträntika tenet by later Buddhist and non-Buddhist sources, ${ }^{1)}$ it is by means of inference that we can cognize the existence of external objects. On the contrary, external things themselves are often referred to as perceptible in Dharmakirti's theory of perception, since they are treated as the particular (svalakșana), i.e., the object of perception. ${ }^{2)}$ In his recent study Prof. Dreyfus described this issue as a kind of conflict between 'direct realism' and 'representationalism', considering how it was argued in the pramāna tradition of Tibetan Buddhism. ${ }^{3)}$ Little attention, however, has so far been given to the question whether Dharmakirti and his successors in India had already been conscious of this issue or not. The aim of this short paper is to examine how the proof of the existence of external objects can agree with Dharmakirti's theory of perception, but here I limit the discussion mainly to the Indian commentaries on PV III 390d-39lab and PVin I 59d.

2. The context in which this proof comes into question is closely linked with Dharmakirti's well-known statement that cognition itself is identical with its object, i.e., cognitive form. The 'given' inside our mind is regarded not as an external object, but as a cognitive form, which is thrown into our cognition by force of the external object. In this connection, the proof is referred to in PV III 390d-39lab. If there arises no sensory cognition in spite of the presence of every other cause, one can infer the existence of another cause, i.e., an external object. ${ }^{6)}$ As stated in PV III 39lab (and PV III 336), however, this proof is valid unless we realize that our cognition is produced merely by an internal and immediate cause (saman- 
antarapratyaya), i.e., latent impressions. Paraphrasing PV III 390d, Devendrabuddhi definitely affirms that external objects are cognizable by inference, but not by perception. ${ }^{7)}$ According to Manorathanandin's commentary too, which must have been borrowed partly from Devendrabuddhi, the apparent perceptibility of external objects is not acceptable even before one quits the externalism and turns to the Yogācāra doctrine. ${ }^{8)}$ Furthermore, Manorathanandin attributes this proof to an anonymous opponent (para), by introducing it with syād etat. ${ }^{9)}$ Here he seems to look it upon as irreconcilable with the Yogācāra doctrine, in which the latent impressions are adopted as the causal factor of our cognition. We should notice that Jinendrabuddhi also cites this proof in his commentary on PS I 9ab. ${ }^{10)}$ Immediately after explaining that cognition itself is never different from its object, he introduces the proof as a supposed objection. Judging from these facts, it would be reasonable to consider if the Sautrāntika doctrine, which involves the proof of the existence of external objects, can always be understood as conforming to the Yogäciàra doctrine in Dharmakirti's epistemology. ${ }^{11)}$

Let us now turn to PVin I 59d, which is also preceded by the statement of the non-difference between cognition and its object. Following this statement, Dharmakirti supposes the question how we can cognize the existence of something different from the manifestation (snan $b a$ ) of a cognitive form inside our mind. In his commentary, Dharmottara paraphrases this question as follows:

If that which is established as perceptible (in our cognition) is not the (external) thing, which is distinct (from the cognition inside our mind), how is it to be ascertained that it (i.e., the external thing) is existent? ${ }^{12}$

As the answer for this question, he introduces PVin I 59d, where the proof of the existence of external objects is indicated simply by the term 'exclusion' (Idog pa, vyatireka). ${ }^{13)}$ This paraphrase of Dharmottara implies that he had the perceptibility of external objects on his mind, although Jñānaśrībhadra makes no particular mention of it. 
3. Concerning the perceptibility of external objects, most noteworthy is the following passage in Prajñākaragupta's commentary on PV III 391ab:

[Question:] Then, how can it (i.e., external thing) be the object of perception? [Answer:] It is by means of metaphorical expression (upacāra) that (external thing is accepted as the) object (of perception), since there is no other alternative than (admitting that) the (cognitive) form (of external thing) is the object of perception. ${ }^{14)}$

Interestingly enough, he reduces the perceptibility of external objects to 'metaphorical expression' (upacīra). Ravigupta also follows Prajñākaragupta's idea, even though he does not explicitly refer to the term upacāra. ${ }^{15)}$

As is generally known, Dharmakirti explains the object of sensory cognition (indriyajiñana) as the aggregate of atoms (paramānu), which possesses the ability to cause its cognition. ${ }^{16)}$ He also equates sensory cognition with non-conceptual perception, since the aggregate of atoms is thought to be not the universal (sāmānyalakșana) but the particular, i.e., the object of perception. This is a valid argument, so long as we take into account that Dharmakirti received the pramānaviplava theory from Dignāga. According to the Sautrāntika doctrine, however, the causality of cognition requires a time gap between cause (object) and effect (cognition), as Dreyfus acutely pointed out. ${ }^{17)}$ The problem increases when this time gap associates itself with the statement that any object, which has already disappeared at the last moment, cannot be directly perceptible. ${ }^{18)}$ In that sense, Prajñākaragupta's interpretation is suggestive of the way in which the perceptibility of external objects can avoid conflicting with their imperceptibility postulated in the proof of the existence of external objects.

4. In concluding, I should note that the following two epistemological aspects are to be differentiated in Dharmakirti's externalism: (1) external objects are directly perceptible; (2) the existence of external objects is cognizable only by means of inference. While ( 1 ) is associated mainly with Dharmakirti's theory of sensory (or mental) perception, (2) is rather subordinate to the context of self-awareness (svasamvedana). These two aspects are not contradictory to each other, if ( 1 ) is to be 
seen as upacāra from the Sautrāntika viewpoint, as Prajñākaragupta suggested. However, it remains to be proved whether we may introduce the two distinct levels of truth into these aspects of Dharmakirti's externalism or not.

(This research is supported in part by a Grant-in-Aid for Young Scientists (B) from JSPS)

*I am obliged to Prof. Shōryū Katsura for his valuable comments and suggestions.

\section{〈Primary Sources〉}

AD: Abhidharmadīpa with Vibhāṣāprabhāvṛtti. Ed. Padmanabh S. JAINI, Patna 1977. TBh: Tarkabhāsāa and Vädasthāna of Mokșākaragupta and Jitāripāda. Ed. H. R. R. IYENGAR, Mysore 1952. NB: Nyāyabindu (Dharmakīrti), in: Pandita Durveka Miśra's Dharmottarapradipa. Ed. D. Malvania, Patna ${ }^{2} 1971$. NM II: Nyāyamañjarī of Javantabhatta with Tippaṇi - Nyāyasaurabha by the Editor. Ed. K. S. VARADACHARYA, Vol. 2, Mysore 1983. PrP: Prakaraṇapañcikā of Śri Śälikanātha Miśra with Nyāyasiddhi. Edited with Introduction and Notes by Subrahmanya SASTRI, Varanasi 1931. PV III: Pramānavārttika (Dharmakīrti) chapter 3 (Pratyakșapariccheda), in: The Pramānavārttikakārikā (Sanskrit and Tibetan). Ed. Y. MiYASAKA, Acta Indologica 2 (1971/72), 1-206. (The numbering of verses follows TOSAKI 1985.) PVA: Pramāṇavārttikabhāșyam or Vārttikālanikārah of Prajñākaragupta. Ed. R. SĀṄkṛtyāyana, Patna 1953. PVin I: cf. Vetter 1966. PVinṬ(J): Pramānaviniścayațīà (Jñānaśrībhadra). P5728, D4228. PVinṬ(D): Pramānaviniścuyıutikā (Dharmottara) chapter 1, 2. P5727, D4229. PVṬ(R): Pramānavārttikaṭikā (Ravigupta). P5722, D4225. PVP: Pramānavārttikapañjikā (Devendrabuddhi). P5717, D4217. PVV: Dharmakirti’s Pramānavārttika with a commentary by Manorathanandin. Ed. R. SĀं̀̃ĀṚTYĀYANA. Patna

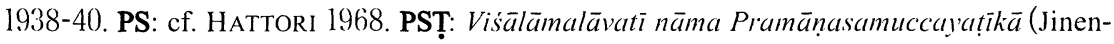
drabuddhi). P5766, D4268. Vś: Vimśsatikā Vịñaptimātratāsiddhi (Vasubandhu). Ed. SyLVAIN LÉvi, Paris, 1925. SDS: Sarva-Darśana-Samgraha of Sāyaṇa Mãdhava. Ed. with an Original Commentary in Sanskrit by, V. S. ABHYANKAR, seen through the press by $T$. G. MAINKAR. Poona ${ }^{3} 1978$.

\section{〈Secondary Sources〉}

DREYFus 1997: Georges B. J. DREYFus, Recognizing Reality, Dharmakirti's Philosophy and Its Tibetan Interpretations, New York. Dunne 2004: John D. Dunne, Foundations of Dharmakirti's Philosophy, Boston. HATTORI 1968: Masaaki HATTORI, Dignäga, On Perception, Cambrige, Massachusetts. IwATA 1991: Takashi IwATA, Sahopalambhanivama, Stuttgart (Alt- und Neu-Indische Studien 29, I-II). KANAKURA 1955: Enshō KanaKURA, Gekyō no bunken ni mieru kyōbu setsu, Indogaku bukkyōgaku ronsō: Yamaguchi Hakushi 
kanreki kinen, 55-68. Kyuma 2005b: Taiken Kyuma, Sein und Wirklichkeit inder Augenblicklichkeitslehre Jñānaśrīmitras. Kșaṇabhañgādhyāya Kapital I: Pakșadharmatādhikāra. Sanskrittext und Übersetzung. Wien (forthcoming). MIMAKI 1972: Katsumi MiMAKI, Shoki yuishiki ronsho ni okeru Sautrāntika setsu, Tōhōgaku 44, 77-92. MIMAKı 1988: 2 Kyōryōbu, Iwanami kōza tōyō shisō 8 (Indo Bukkyō 1), Tokyo, 226-260). OKI 1982: Kazufumi OKI, Jisō ni tsuite, Mikkyōgaku Kenky'ü 14, 99-114. Tanizawa 2002: Junzō Tanizawa, Dharmakïrti ni miru bukkyō ronrigakuha no chikakuron no chokusetsu jitsuzaironteki keikō, Indo Tetsugaku Bukkyōgaku Kenkyū 9, 17-28. TORELla 2002: Raffaele TORELla, The İsvarapratyabhijñăkārikā of Utpaladeva with the Author's Vṛtti, Critical Edition and Annotated Trunslation, Delhi. TOSAKI 1979: Hiromasa TOSAKI, Bukkyō ninshikiron no kenkyü jōkan (Volume 1), Tokyo. TosaKi 1985: ibid. gekan (Volume 2). VeTter 1964: Tillmann VETTER, Erkenntnisprobleme bei Dharmakirti. Wien. VETTER 1966: Dharmakirti's Pramānaviniścayah, 1. Kapitel: Pratyakșam. Einleitung, Text der tibetischen Übersetzung, Sanskritfragmente, deutsche Übersetzung. Wien. Yoshimizu 2003: Chizuko Yoshimizu, Review Article for DReyfus 1997, Indo-Iranian Journal 46-4, 349-368. YŪKI 1986: Reimon YūKI, Seshin yuishiki no kenkȳü jou (Volume 1), Tokyo.

\section{〈Notes〉}

1) Cf. Kanakura 1955; Tosaki 1985: 73, fn. 71; as well as PrP 177,4-11; Torella 2002: 112-113, fn. 9. The prototype of this proof can be traced to the argument of Vś k. 2, which is attributed to the Sautrāntika (cf. MIMAKI 1972: 84ff.; 1988: 245ff.; YŪKI 1986: 354ff.). Prof. Mimaki suggests the possibility that this theory of inference had already been presupposed in the Abhidharmakośa(-bhāsya), since bāhyārthavāda and sākārajñānavāda, both of which should encompass the theory of inference, are to be found there (cf. MIMAKI 1972: 79ff.; 1988: 246). In any case, it would also be necessary to consider when such a primordial theory was actually formulated into a logical proof. In this regard, it is also to be noted that Vasubandhu, as Yogäcürin, insists on the imperceptibility of external objects in Vś 8,29ff. On the other hand, this imperceptibility is related to the Därștāntika in AD 47,13ff. (cf. also AD 32,9-10 and fn. 2.)

2) Cf. PV III lab'; PVin I 32,1f.; NB I 8-9; 12 etc., as well as OKI 1982: 104ff. In contrast, the imperceptibility of external objects is suggested in PV III $348 \mathrm{~b}$ etc. This 'epistemological' inconsistency is concisely expressed in SDS 43, 9-1l (cf. MIMAKI 1972: 77, fn. 83). As concerns this inconsistency, it has recently been pointed out that direct realism is one of the basic traits of Dharmakirti's theory of perception, which has been understood mostly as phenomenalism or representationalism. Cf. TANIZAWA 2002: 20ff. He concludes that the following two phases are to be distinguished in Dharmakirti's theory of perception: (l) we directly perceive external objects (= a kind of direct realism), (2) we perceive the cognition itself (= svasamvedana, which might correspond to 'sense-datum' in Western 
philosophy) brought about by (1).

3) Cf. DReyfus 1997: 4l6ff. Some modifications have recently been made to Dreyfus' classification of Dharmakirti's ontology in DUNNE 2004: 69ff., where Prof. Dunne discriminates between the following four stages: (1) the belief of ordinary persons, (2) the abhidharma typology, (3) external realism (Dunne suggests that this stage might be called Sauträntika), (4) epistemic idealism. The direct perceptibility of external objects might be allocated to (1) / (2), and the proof of their existence to (3) in Dunne's classification. As Dunne himself suggests (cf. ibid. : 59, fn. 13), however, it is doubtful whether one may confine the term 'external realism' only to the Sautrāntika ontology. In this paper I tentatively use the term 'externalism' or 'external realism' in a broad sense, i.e., as subsuming all of (1)-(3) in Dunne's classification.

5) These verses are translated into German in VETTER 1964: 74: IWATA 1991 (Teil I): 5. For Japanese translation, cf. TOSAKI 1985: 73ff.

6) This proof is named hetubhedānumā in PV III 390d. Devendrabuddhi interprets the compound hetubheda as 'another cause' (rgyu gźan, PVP P277a6 = D234b6), while Ravigupta and Manorathanandin read it as 'a specific cause' (kāranavišeșa / rgyu'i khyad par, see, eine besondere Ursache' in VETTER 1964 and IWATA 1991). Cf. PVṬ(R) Pl67b4 $=$ Dl40a6; PVV 236,4. The term vyatireka, which is common to PVin I $59 \mathrm{~d}$, is used for indicating this proof in PVP P277a5 = D234b6; PVV 236,5. It is fairly surprising that Prajñākaragupta defines this proof not only as vyatirekimātra but also as sāmānyato d!̣sțta in PVA 411,9. We may note, in passing, that the archetype of another proof, whose reason is the recollection (smrti) of external objects, is suggested in Vś 9,1-2. Cf. also MIMAKI 1972: 79 , fn. 83 .

7) PVP P277a6-7 = D234b6-7. Śākyabuddhi seems to pay no particular attention to this point.

8) PVV 236,5-6.

9) PVV 265,25ff.; $236,5$.

10) PST P36al-3 = D3lb6-32al.

11) For this conformity, cf. IWATA 1991 (Teil I): 4. Nonetheless, Dharmakirti's wording such as PV III 34la and PV III 345'b suggests that he was never indifferent to the epistemological consistency between both doctrines.

12) $\operatorname{PVinTT(D)~} \mathrm{P} 194 \mathrm{a} 4=$ Dl66a6-7.

13) The term vyatireka / ldog pa, which means 'negative concomitance' in the context of logic, is paraphrased as kâryavyatireka / 'bras bu ldog pa, i.e., the exclusion of effect (= cognition) in PVP P277a5 = D234b6; PVinṬ(J) P239b4 = D201b7; PVinṬ(D) Pl94a8 $=$ Dl66a7. Some parallel passages are found in NM II 492,7 (cf. PVin I 100, fn. 1); TBh 64,3-4: KYUma 2005a: 8,6-7 (and fn. 54 in German translation).

14) PVA 411,12-13. The perceptibility of external objects is also rejected in PVA 390,24f. (ad PV III 336); 411,5-6. 
15) $\mathrm{PVTT}(\mathrm{R}) \mathrm{Pl} 67 \mathrm{~b} 4-5=\mathrm{Dl} 40 \mathrm{bl}-2$. Ravigupta also relates don rig pa (arthavedana) to tha sñad (vyavahāra) in PVṬ(R) Pl55a3 = Dl28b7-129al (cf. TOSAKI 1985: 36, fn. 132; PVA 395,3-4).

16) This minimum causal efficacy (arthakriyāisakti), called viśeșa or atišaya in PV III 195-196 and 223-224, guarantees not only the immediacy of sensory perception but also the non-conceptual perceptibility of external objects. For the close connection between the Sautrānika doctrine and Dharmakirti's idea of visessa / atiśaya, cf. Mimaki 1972: 90ff.; TOSAKI 1979: 37ff. In PV III 224 and 247, this ability is identified with one of the two conditions for ālambanatva defined in Dignāga's Allambanaparīkșā, k. 6 .

17) Cf. DReyfus 1997: 4l6ff. In spite of this time gap, Dharmakirti regards the sensory cognition, which arises one moment later than sensory organ and object, as the non-conceptual perception, for which no intermediary factor should be required. This might be an important clue to the tension between direct realism and representationalism in Dharmakirti's philosophy. Cf. also PV III54cd; ОкI 1982: 103ff.; Yoshimizu 2003: 365ff.

18) For this statement, cf. AD 47,13ff.; Vś 8,31-9,1.

〈Key Word〉 anumāna, bāhyārtha, Dharmakīrti, pratyakșa, Sautrānika, Yogācāra

(Associate Professor, Mie University, Ph.D.) 